\title{
Brain Wave and Electromyography Responses to Butorphanol during Ketamine- and Halothane-Induced Anaesthesia in Horses
}

\author{
P. KRULJC, V. CESTNIK \\ University of Ljubljana, Veterinary Faculty, Clinic for Reproduction and Horses and Institute for Physiology, \\ Pharmacology and Toxicology, Ljubljana, Slovenia \\ Received March 24, 2001 \\ Accepted November 18, 2002
}

Abstract

Kruljc P., V. Cestnik: Brain Wave and Electromyography Responses to Butorphanol during Ketamine- and Halothane-Induced Anaesthesia in Horses. Acta vet. Brno 2003, 72: 41-47.

According to clinical experience the use of butorphanol is suitable for the deepening of sedation and analgosedation and is also used in premedication for general anaesthesia. Our presumption was that the depth of anaesthesia in horses that we earlier defined by the parameter $\mathrm{SEF}_{90}$, is the same as in humans. We proved this hypothesis by using a pEEG monitor. We also proved that the monitor we used is an important instrument for the depth and safety control in equine anaesthesia.

In this study using 10 horses we established the influence butorphanol administered with detomidine has on EEG and EMG on the left temporal muscle. Both drugs were applied for premedication in ketamine-induced and halothane-induced anaesthesia. The EEG $\left(\mathrm{SEF}_{90}\right)$ and EMG measurements were performed with a pEEG monitor with a computer-modified programme, while heart rate, blood pressure, $\mathrm{SpO}_{2}, \mathrm{EtCO}_{2}$ and respiratory rate were measured by means of an anaesthesia monitor. Based on the brain's electrical activity (EEG) and electrical activity of the left temporal muscle (EMG) it was established that the addition of butorphanol in premedication caused a significant reduction of $\mathrm{SEF}_{90}$ and $\mathrm{EMG}$ values during ketamine-induced and halothaneinduced anaesthesia. An increase of heart rate, blood pressure and decrease of respiratory rate occurred during anaesthesia with ketamine while halothane anaesthesia also caused an increase in $\mathrm{SpO}_{2}$. No correlations were found between $\mathrm{SEF}_{90}, \mathrm{EMG}$ and other measured parameters.

Veterinary medicine, detomidine, butorphanol, ketamine, halothane, EEG, EMG, horse

Good general anaesthesia causes sleep, muscle relaxation and an absence of pain response (Mysinger et al. 1985) due to a change in electrical activity in the brain. The latter is manifested in changes of brain wave shapes. The level of the central nervous system, inhibition and the EEG during anaesthesia depend on the dose and effect of the applied active ingredients on cerebrocortical electrical activity (Litscher et al. 1995; Muir and Hubbell 1991).

The measurement and analysis of brain waves and regular monitoring was made possible with the development of computer-assessed EEG analysis (spectral analysis), as well as the control of brain electrical activity and the depth of anaesthesia as a consequence of the effect of the applied active ingredients (Dick et al. 1992; White et al. 1989; Otto and Short 1991). Thus EEG is also useful in researching the influence of different active ingredients on the central nervous system (Litscher et al. 1995).

EEG and EMG are two important parameters for determining the depth of anaesthesia and muscular relaxation. SEF (Spectral Edge Frequency) is a parameter in EEG, which is in correlation with the depth of hypnosis or sleep and is used to assess the depth of analgesia. The depth of analgesia changes depending on the change of brain activity reflected on the individual, the variety presence of brain electrical activity or the change of amplitude (voltage) and frequency of brain waves $(\mathrm{Hz})$. The most important unit of SEF is the so-called $\mathrm{SEF}_{90}$, which represents a frequency below where 90 per cent of the interval of brain wave

Address for correspondence: Peter Kruljc, DVM, MSc, PhD Clinic for Reproduction and Horses, Cerinary Faculty, University of Ljuban Gerbičeva 60, 1000 Ljubljana, Slovenia
Phone: +386 14779325

E-mail: peter. kruljc@vf.uni-lj.si

http://www.vfu.cz/acta-vet/actavet.htm 
frequency spectrum is located (Litscher et al. 1995). Therefore, SEF90 was used as a measure of brain electrical activity $(\mathrm{Hz})$ and $\mathrm{EMG}(\mu \mathrm{V})$ was used as a measure of muscular activity in our study.

The aim of the study was to investigate the influence of opioid analgesic butorphanol administered in premedication in conjunction with detomidine on EEG and EMG of the left temporal muscle during ketamine-induced and halothane-induced anaesthesia in horses. Heart rate and respiratory rate, blood pressure, $\mathrm{SpO}_{2}$ and $\mathrm{EtCO}_{2}$ were monitored simultaneously.

\section{Materials and Methods}

The experiment was performed on ten horses, four geldings and six mares, between six and eight years, of coldblooded breed.

The monitor used in this study to control brain functioning was the pEEG monitor (processed EEG monitor, made by Dräger, Lübeck, Austria, version 3.01) with computerized processed electroencephalography and electromyography, a dual channel, a bipolar frontal, a frequency range of 1.5 to $30 \mathrm{~Hz}$, amplitude - potential range 25 to $200 \mu \mathrm{V}$, which receives and modifies two EEG signals from the left and right cerebral hemispheres by means of five direct current electrodes (Agilent Technologies, Neonatal/Paediatric Solid Gel ECG Monitoring Snap Electrode, No. 13951C). By means of quick Fourier transformation the pEEG monitor provides (period) an adequate amplitude $(\mu \mathrm{V})$ for each frequency of the EEG signal $(\mathrm{Hz})$ every two seconds, as well as the representations of individual brain wave frequencies, which the monitor calculates from the data of raw (computer unprocessed) EEG. The control of electrode resistance, which impedance must be between 0 to $40 \mathrm{k} \Omega$ is automatic. From the left pair of them the pEEG monitor carries out the measurements and also provides the EMG activities of the left temporal muscle (electromyography), which indicates its electrical activity and the level of relaxation of this striated muscle (Fig. 1). Electrodes for the EEG and EMG are identical.

\section{Drager pEEG plus v3.01}

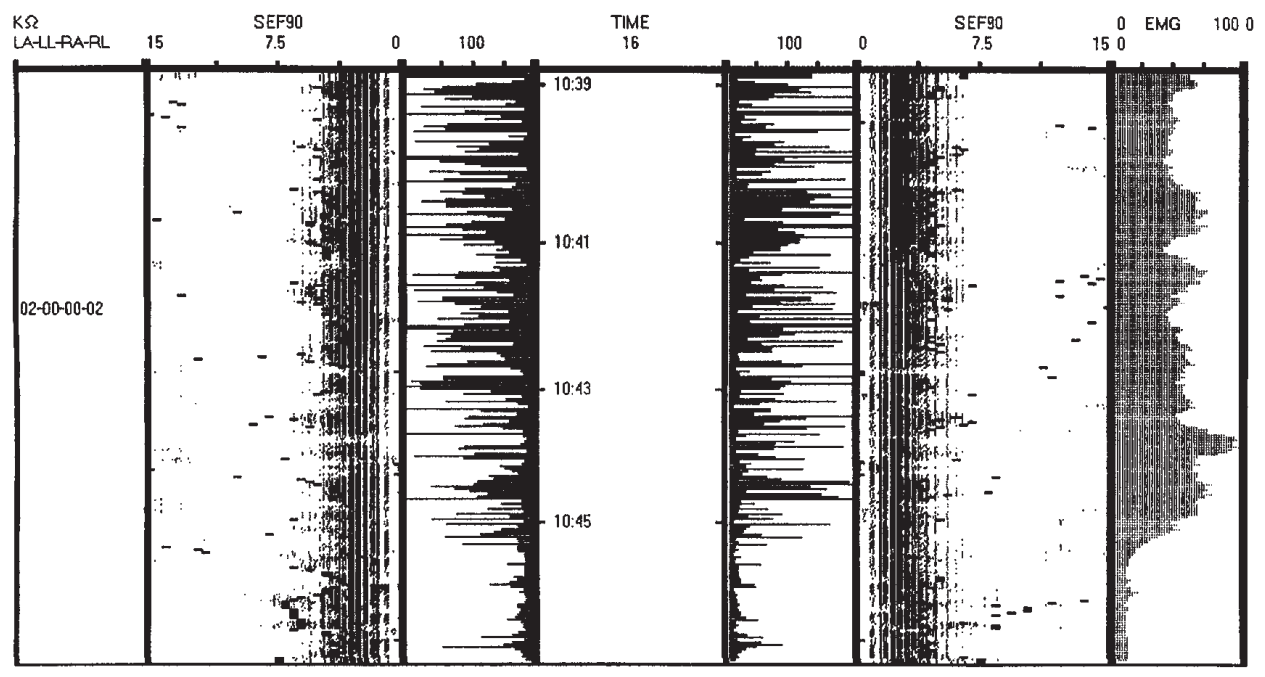

Fig.1. EEG $\left(\mathrm{SEF}_{90}\right)$ and EMG

The effects of added butorphanol were examined by monitoring electrical activity in the brain $\left(\mathrm{SEF}_{90}\right)$ and EMG of the left temporal muscle. The first measurements of EEG, EMG and other parameters were carried out prior to the experiment and were measured with a pEEG monitor on animals that were standing and completely awake, without using drugs and then during general ketamine-induced and halothane-induced anaesthesia. Electrodes were attached to the designated shaved places on the head (in the middle of reg. frontalis on both sides, in the middle of reg. parietalis on both sides of the head and in the upper third of the suture interfrontalis) and were connected to the pEEG monitor. The changes of the EEG waves were read from the screen. The pEEG monitor was directly linked to a PC. 
The other parameters (heart rate, blood pressure, $\mathrm{SpO}_{2}, \mathrm{EtCO}_{2}$, respiratory rate) were measured by means of an anaesthesia monitor Hewlett Packard HS 66 and accompanying modules. Heart rate (beats per minute) was monitored by ECG and five electrodes attached to the shaved places of the animal's body (left and right side of thorax region, left and right side of the abdominal region and in the middle of the xiphosternum region). Beats per minute and $\mathrm{SpO}_{2}$ were measured with the module for pulse oxymetry, which simultaneously measures beats per minute as well. A clip with a sensor was placed on the animal's tongue. $\mathrm{CO}_{2}$ in exhaled air was measured with the module for capnometry. The sample-taking point was at the section $\mathrm{Y}$ of the tube for supply and outlet of gases. The accompanying module regularly took and analysed the quantity of $\mathrm{CO}_{2}$ in the exhaled air. Due to technical obstacles $\mathrm{SpO}_{2}$ and $\mathrm{EtCO}_{2}$ were measured only during both anaesthesia. Non-invasive arterial pressure was measured with a multi-patient comfort reversible cuff (Agilent Technologies, Böblingen, Germany, mod. M1574A, $14 \mathrm{~cm}$ wide, diameter $26.5-38 \mathrm{~cm}$ ) on the tail artery at the root of the tail. This painless method of blood pressure measurement least agitated the animals and was the same method we used on animals that were standing and completely awake, before induced anaesthesia with ketamine and halotane. Respiratory rate was monitored with electrodes for ECG measurement, on the lining of changes of impedance between electrodes. All horses were recumbent on the right lateral position during anaesthesia.

During five minutes prior to the experiment (with no added active ingredients) the basic measurements of $\mathrm{SEF}_{90}$, EMG and the other parameters were carried out in all the horses. Premedication detomidine - (Domosedan, Orion corporation, Finland) $(22.0 \mu \mathrm{g} / \mathrm{kg}$, i/v) was administered in both groups of horses $(\mathrm{n}=2 \times 5)$, while butorphanol (Torbugesic, Fort Dodge Animal Health, Fort Dodge, USA) $\left(0.05 \mathrm{mg} \cdot \mathrm{kg}^{-1}, \mathrm{i} / \mathrm{v}\right)$ was added in the second group $(\mathrm{n}=5)$ ten minutes later. In the $20^{\text {th }}$ minute ketamine (Ketamine $10 \%$, Veyx-Pharma GmbH, Schwarzenborn, Germany) (2.2 $\left.\mathrm{mg} \cdot \mathrm{kg}^{-1}, \mathrm{i} / \mathrm{v}\right)$ was administered in bolus to both groups, initiating anaesthesia. After five minutes, when the horses had laid down and had been intubated and connected to the anaesthesia monitor, a 20-minute measurement was performed. Then anaesthesia was prolonged with $1 / 3$ of the induction dose of ketamine $(0.74$ $\mathrm{mg} \cdot \mathrm{kg}^{-1}$ ) in both groups and general anaesthesia with halothane was initiated. Initially, a 5 vol\% mixture of halothane (Fluotane, Zeneca Limited, United Kingdom) and an oxygen flow of $17.6 \mathrm{ml} / \mathrm{kg} / \mathrm{min}$ were used and as the anaesthesia deepened the percentage of halothane was gradually reduced. When the anaesthesia was deep enough and only the palpebral reflex was present (Riebold et al. 1995a), halothane was limited to a 2 vol\% and an oxygen flow of $13.2 \mathrm{ml} / \mathrm{kg} / \mathrm{min}$. A 20 -minute measurement was carried out and then they started to wake-up.

The data that was recorded every minute by the monitor was used for the analysis. The collected results were compared and statistically processed by means of the variance and correlation analysis (Microsoft Excel 6.0, statistical programme ANOVA and correlation test according to Pearson).

Table 1

Average values and standard errors

\begin{tabular}{|c|c|c|c|c|c|c|c|c|c|c|}
\hline & \multicolumn{2}{|c|}{ Base values } & \multicolumn{4}{|c|}{ Anaesthesia with ketamine } & \multicolumn{4}{|c|}{ Anaesthesia with halothane } \\
\hline & & & & & Gro & p II. & & & Grc & II. \\
\hline & & SEM & & SEM & & SEM & & SEM & & SEM \\
\hline $\mathrm{SEF}_{90} \mathrm{~L}(\mathrm{~Hz})$ & 19.9 & \pm 1.1 & 17.9 & \pm 0.8 & 16.6 & \pm 0.8 & 7.6 & \pm 0.2 & 8.6 & \pm 0.3 \\
\hline $\mathrm{SEF}_{90} \mathrm{R}(\mathrm{Hz})$ & 20.2 & \pm 1.1 & 18.3 & \pm 0.8 & 16.01 & \pm 0.8 & 8.5 & \pm 0.3 & 8.5 & \pm 0.3 \\
\hline $\operatorname{EMG}(\mathrm{V})$ & 63 & \pm 4.6 & 44.8 & \pm 3.8 & 35.6 & \pm 3.3 & 5.6 & \pm 0.5 & 5.6 & \pm 0.4 \\
\hline Heart rate & 48.1 & \pm 2.6 & 35.6 & \pm 0.7 & 42 & \pm 1.03 & 39 & \pm 0.4 & 42.7 & \pm 0.6 \\
\hline $\begin{array}{l}\text { Blood pressure - } \\
\text { systolic }(\mathrm{mmHg})\end{array}$ & 102.6 & \pm 4.9 & 135.3 & \pm 1.2 & 151.9 & \pm 2.6 & 90.7 & \pm 1.2 & 101.8 & \pm 1.5 \\
\hline $\begin{array}{l}\text { Blood pressure - } \\
\text { diastolic }(\mathrm{mmHg})\end{array}$ & 61.3 & \pm 5.3 & 84.1 & \pm 1.2 & 90.3 & \pm 2 & 52.1 & \pm 1.8 & 60.2 & \pm 1.3 \\
\hline $\begin{array}{l}\text { Blood pressure - } \\
\text { mean }(\mathrm{mmHg})\end{array}$ & 74.7 & \pm 4.8 & 102 & \pm 1.1 & 111.1 & \pm 2.1 & 64.3 & \pm 1.5 & 74.1 & \pm 1.2 \\
\hline $\mathrm{SpO}_{2}(\%)$ & & & 86.1 & \pm 0.4 & 86.8 & \pm 0.2 & 92.7 & \pm 0.3 & 93.6 & \pm 0.3 \\
\hline $\mathrm{EtCO}_{2}(\mathrm{mmHg})$ & & & 33.4 & \pm 0.8 & 32.2 & \pm 0.5 & 48.6 & \pm 0.8 & 48.7 & \pm 0.5 \\
\hline $\begin{array}{l}\text { Respiratory } \\
\text { rate }\end{array}$ & & & 20.8 & \pm 0.9 & 12.8 & \pm 0.5 & 13.7 & \pm 0.5 & 10.8 & \pm 0.3 \\
\hline
\end{tabular}

Legend: $\mathrm{SEF}_{90} \mathrm{~L} \quad$ left cerebral hemisphere

$\mathrm{SEF}_{90} \mathrm{R}$ right cerebral hemisphere

Group I. detomidine administered in premedication

Group II. detomidine + butorphanol administered in premedication

Heart rate beats per minute 


\section{Results}

The table presents the average values of means and standard errors of $\mathrm{SEF}_{90}$, electromyography (EMG) of the left temporal muscle, heart rate, blood pressure, $\mathrm{SpO}_{2}$, $\mathrm{EtCO}_{2}$ and respiratory rate.

a) Anaesthesia with ketamine

The values of brain electrical activity (EEG), left temporal muscle potential (EMG) and other hemodynamic and respiratory parameters in awake and inactive horses, measured prior to the experiment, were used as the base values.

Horses in Group I received only detomidine in premedication. $\mathrm{SEF}_{90}$ was similar to the base values, while it was significantly lower in Group II (left cerebral hemisphere $P=0.02$ / right cerebral hemisphere 0.001). EMG of the left temporal muscle was lower (left cerebral hemisphere $\mathrm{P}=0.004$ and right cerebral hemisphere $P<0.001)$ in both groups. Heart rate was lower $(P<0.001)$ only in Group I, while in Group II it was non-significantly lower. Blood pressure was higher $(P<0.001)$ in both groups, but the increase was smaller in Group I. Respiratory rate was lower in Group II compared to Group I.

Comparison between the two groups: $\mathrm{SEF}_{90}$ was significantly lower although only in the left hemisphere in Group II, while there was no significant difference in EMG $(P=0.07)$. Heart rate and blood pressure were higher in Group II $(P<0.001)$, while $\mathrm{SpO}_{2}$ and $\mathrm{EtCO}_{2}$ values did not differ in the two groups. Respiratory rate was lower in Group II $(P<0.001)$, but still within physiological limits.

b) Anaesthesia with halothane

$\mathrm{SEF}_{90}$ and EMG decreased $(P<0.001)$ in both groups. Heart rates were lower $(P<0.001)$ in both groups. Blood pressure significantly decreased $(P=0.04)$ only in Group I, while the change of pressure was non-significant in Group II.

$\mathrm{SEF}_{90}$ was significant $(P=0.01)$ in Group I, but only in the left cerebral hemisphere. EMG of the left temporal muscle did not significantly differ between the two groups. What was higher in Group II were blood pressure $(P<0.001)$, heart rate $(P<0.001)$ and $\mathrm{SpO}_{2}$ $(P=0.03)$, while respiratory frequency was lower $(P=0.001) . \mathrm{EtCO}_{2}$ did not differ in the two groups.

\section{Discussion}

The values of $\mathrm{SEF}_{90}$ during the in anaesthesia horses with ketamine were removed from $8-12 \mathrm{~Hz}$ in in both groups, which presents a deep surgical anaesthesia in humans (Lit scher et al. 1995). Only the anaesthesia with halotane reached those values. The measured values indicated high electrical activity in the brain in both groups despite the fact that the horses were laying down and sleeping during anaesthesia. Irrespective of the fact that compared to the base values $\mathrm{SEF}_{90}$ decreased by a significant margin only in the second group. Comparing the two groups showed no significant differences.

Ketamine itself induces poor muscular relaxation (Riebold et al. 1995b). However, compared to the initial values, muscular relaxation was higher by a significant margin in both groups. This fact can be attributed to the consequences of the effect of detomidine administered in premedication (Muir et al. 1995a), which provides good muscular relaxation. In Group II, relaxation was somewhat higher, but the difference was not significant. This can be explained by the addition of butorphanol in premedication, which in conjunction with detomidine deepens sedation and muscular relaxation. This could also account for lower potential in the left temporal muscle. Nevertheless, the effect of butorphanol during ketamine-induced anaesthesia did not considerably enhance the 
relaxation. Considering $\mathrm{SEF}_{90}$ and $\mathrm{EMG}$ values we can conclude that neither group experienced deep general anaesthesia and that added butorphanol in premedication did not cause considerable significant differences in the depth of anaesthesia $\left(\mathrm{SEF}_{90}\right)$, i.e. it did not induce greater inhibition of the central nervous system and greater muscular relaxation.

During induction ketamine has an effect directly on the cardiovascular system manifested in an increase of blood pressure and heart rate (Riebold et al. 1995b). Blood pressure in both groups increased compared to the base values. A comparison between the two groups showed that blood pressure was significantly higher in the second group. This difference can be explained by the effect of butorphanol, which, being an opioid, may increase blood pressure (Riebold et al. 1995c).

Compared to the base values, heart rate wase reduced in only in Group I $(P<0.001)$. A comparison between the two groups indicated an increase in heart rate in Group II $(P<$ 0.001). Ketamine increases heart rate (Riebold et al. 1995b), while detomidine slows it down (Muir et al. 1995b). Butorphanol, which was administered to Group II, has a low inhibitory effect on heart rate (Muir et al. 1995c), however, the given combination increased it $(P<0.001)$.

Respiratory rate was lower in Group II $(P<0.001)$. Ketamine reduces respiratory frequency and volume and may even cause apnoea. Respiratory inhibition and the intensity of clinical signs depend on the dose. Higher doses may cause breathing inhibition, hypoxemia and hypercarbia. Respiratory rate increases later on, which in our opinion is the cause of a higher respiratory rate in Group I. In comparison with ketamine, butorphanol does not cause distinct respiratory inhibition, but it can happen as a result of inhibition of the central nervous system. Respiratory volume usually increases, while minute volume; $\mathrm{PaO}_{2}$ and $\mathrm{PaCO}_{2}$ remain unchanged (Roberts on et al. 1981). The sensitivity of the respiratory centre for $\mathrm{PaCO}_{2}$ may be reduced. Hyperventilation may occur in deeply sedated horses, and apnoea may occur in anaesthetised horses (Hall et al. 1991). Its effect in the form of inhibition of the central nervous system can be seen as the cause of reduced respiratory rate in the second group. Detomidine also reduces respiratory rate and in higher doses can result in apnoea and tachypnea, while it does not cause changes to $\mathrm{CO}_{2}$ pressure (Muir et al. 1995d). A decrease in respiratory frequency may thus be attributed to the simultaneous effect of all three drugs, each of them reducing respiratory rate in its own way. $\mathrm{SpO}_{2}$ and $\mathrm{EtCO}_{2}$ values did not differ by a significant margin in the two groups.

During anaesthesia with halothane $\mathrm{SEF}_{90}$ increased $(P<0.001)$ in both groups, compared to the first period. A comparison between the two groups showed lower $\mathrm{SEF}_{90}$ values in Group II only in the left cerebral hemisphere $(P=0.01)$. The effect of halothane was reflected in such inhibition of the central nervous system that $\mathrm{SEF}_{90}$ values were reduced to less than half of the initial value, thus bringing about a state which in human medicine is considered to be the level of ideal general anaesthesia and represents surgical anaesthesia.

EMG of the left temporal muscle was reduced in both groups $(P<0.001)$ and did not differ between the two groups, which also points to the fact that during halothane-induced anaesthesia butorphanol did not have a significant effect on the relaxation of the left temporal muscle.

Heart rate decreased in both groups as well $(P<0.001)$, but did not differ significantly between the two groups. This indicates that, unlike ketamine-induced anaesthesia, the effect of butorphanol during halothane-induced anaesthesia was not reflected in a change of beats per minute.

Arterial blood pressure decreased by a significant margin only in Group I $(\mathrm{P}=0.006)$, while it was similar to the initial values in Group II. A comparison between the two groups showed that the pressure in the Group II was higher $(P<0.001)$, which is attributed to the effect of butorphanol on higher blood pressure (Riebold et al. 1995c). Since halothane has 
numerous negative effects on both the vascular system, where it causes peripheral vasodilatation, and the heart, where it has an inhibitory effect on cardiac muscle activity, reduces the stroke volume, heart expulsion and causes bradycardia, and also indirectly on the reduction of blood pressure (Riebold et al. 1995d), butorphanol has a favourable effect on it.

Respiratory rate differed between the two groups $(P<0.001)$. It was lower in Group II. Halothane alone inhibits breathing (Riebold et al. 1995d), while additional inhibition can be attributed to the effect of butorphanol, which may have an inhibitory effect on breathing (Riebold et al. 1995e). $\mathrm{SpO}_{2}$ was higher in Group II $(P=0.03)$, but the difference was so small that in our opinion it is clinically negligible.

A comparison of $\mathrm{SEF}_{90}$ and $\mathrm{EMG}$ of the left temporal muscle during anaesthesia with ketamine and with halothane between the same groups showed that during anaesthesia with ketamine $\mathrm{SEF}_{90}$ and EMG were higher $(P<0.01)$ in both groups. Similarly, blood pressure was also higher $(P<0.001)$ as well as respiratory frequency $(P=0.001)$, while $\mathrm{SpO}_{2}$ and $\mathrm{EtCO}_{2}$ were lower $(P<0.001)$.

We established that the depth of anaesthesia in horses, based on $\mathrm{SEF}_{90}$ measures during anaesthesia with halotane, is comparable with the depth of anaesthesia in humans. No correlations between $\mathrm{SEF}_{90}$, EMG, heart rate, blood pressure, $\mathrm{SpO}_{2}, \mathrm{EtCO}_{2}$ and respiratory rate were determined. The reason for this lies in the fact that the recording of electrical activity in the brain takes place at the moment of its measurement, while changes of the values of other parameters, which may arise as a result of the effect of active ingredients on the brain, appear within different time intervals, thus making it impossible to establish their correlations at a given moment.

\section{Elektroencefalická a elektromyografická odpověd' po podání butorphanolu v průběhu anestézie koní navozené aplikací ketaminu a halotanu}

Na základě klinických zkušeností je použití butorphanolu vhodné pro prohloubení sedace a neuroleptanalgézie a rovněž se používá při premedikaci před celkovou anestézií. Cílem této práce bylo posoudit vliv butorphanolu podaného současně s detomidinem na elektroencefalogram (EEG) a elektromyogram sledované na levém spánkovém svalu. Oba preparáty byly aplikovány za účelem premedikace před celkovou anestézií navozenou ketaminem a halotanem. Měření EEG ( $\left.\mathrm{SEF}_{90}\right)$ a EMG byla prováděna pomocí $\mathrm{pEEG}$ monitoru s počítačově modifikovaným programem, zatímco frekvence pulzu, krevní tlak, $\mathrm{SpO}_{2} \mathrm{EtCO}_{2}$ a frekvence dýchání byly měřeny pomocí anestetizačního monitoru. Na základě získaných hodnot EEG a EMG levého spánkového svalu bylo stanoveno, že zařazení butorphanolu do premedikace mělo za následek statisticky nesignifikantní redukci $\mathrm{SEF}_{90}$ a EMG hodnot v průběhu anestézie indukované ketaminem a halotanem. Při anestézii navozené ketaminem došlo ke zrychlení srdeční frekvence, zvýšení krevního tlaku a zpomalení dechové ferkvence, zatímco během halotanové anestézie došlo navíc ke zvýšení $\mathrm{SpO}_{2}$. Žádné korelace nebyly zjištěny mezi $\mathrm{SEF}_{90}$, EMG a dalšími sledovanými parametry.

\section{References}

DICK, W, GURMAN, G, SCHFER, M, MOECKE, H, 1992: Can pEEG monitoring improve the management of general anaesthesia? Drger, Industrial Forum, Hague, $56 \mathrm{p}$.

GRANDY, JL 1987: Arterial hypotension and the development of postanesthetic myopaty in halothane anaesthetized horses. Am J Vet Res 48: 192 - 197

HALL, LW, CLARKE, KW 1991: Veterinary anaesthesia. $9^{\text {th }}$ ed. Bailliere Tindall London, pp. 203-244

KRULJC, P 2000: EEG $\left(\mathrm{SEF}_{90}\right)$ nad EMG changes to detomidine and butorphanol in the horse. In: 7th World congress of veterinary anaesthesia. Bern, pp. 111

LITSCHER, G, SCHWARZ G, LIST WF 1995: EEG Langzeitberwachung. Der Einsatz des Drger pEEG-Monitors in der Intensivtherapie. Universitatsklinik fr Ansthesiologie, Graz, 31 p. 
MUIR, WW, HUBBELL, JAE 1991: Equine anaesthesia: monitoring and emergency therapy. Mosby, St. Luis, pp. 156

MUIR, WW, HUBBELL, JAE 1995a: Handbook of veterinary anaesthesia. 2nd ed. Mosby, St. Louis, pp. 31-32

MUIR, WW, HUBBELL, JAE 1995c: Handbook of veterinary anaesthesia. 2nd ed. Mosby, St. Louis, p. 30

MUIR, WW, HUBBELL, JAE. 1995b: Handbook of veterinary anaesthesia. 2nd ed. Mosby, St. Louis, p. 36

MUIR, W.W., HUBBELL, J.A.E. 1995d: Handbook of veterinary anaesthesia. 2nd ed. Mosby, St. Luis, p. 20

MYSINGER, PW 1985: Electroencephalographic patterns of clinically normal, sedated and tranquillised newborn foals and adult horses. Am J Vet Res 46: 36-41

OTTO, K, SHORT, CE 1991: Electroencephalographic power spectrum analysis as a monitor of aesthetic depth in horses. Vet Surg 20: 362-71

RIEBOLD, TW, GEISER, DR, GOBLE, DO 1995a: Large animal anaesthesia. Principles and techniques. $2^{\text {nd }}$ ed. Iowa State University Press, Ames, pp. 49-50

RIEBOLD, TW, GEISER, DR, GOBLE, DO 1995b: Large animal anaesthesia. Principles and techniques. $2^{\text {nd }}$ ed. Iowa State University Press, Ames, pp. 26

RIEBOLD, TW, GEISER, DR, GOBLE, DO 1995c: Large Animal Anaesthesia. Principles and techniques. $2^{\text {nd }}$ ed. Iowa State University Press, Ames, pp. 30

RIEBOLD, TW, GEISER, DR, GOBLE, DO 1995d: Large animal anaesthesia. Principles and techniques. $2^{\text {nd }}$ ed. Iowa State University Press, Ames, pp. 59

RIEBOLD, TW, GEISER, DR, GOBLE, DO. 1995e: Large animal anaesthesia. Principles and techniques. $2^{\text {nd }}$ ed. Iowa State University Press, Ames, pp. 102

ROBERTSON, JT 1981: Cardiopulmonary effects of butorphanole tartrate in horses. Am J Vet Res 42: 41-44

WHITE, PF, BOYLE, WA 1989: Relationship between hemodynamic and electroencephalographic changes during general anaesthesia. Anesth Analog 68: 177-181 